\title{
Impact of Judicial Logic on Criminal Sentences
}

\author{
Atef Fahed Almaghareez, \\ UNIVERSIT'E SIDI MOHAMED BEN ABDELLAH DE FES
}

\begin{abstract}
This study aims in the astronomy of the philosophy of judicial logic in order to reveal the important role of sound judicial logic in the construction of criminal judgments, as long as judicial thinking is inevitably based on the rules of sound logic using the methods of judicial inference that reveal the nature of causal links between fixed facts and legal texts. Judicial logic in the curricula of law teaching casts a shadow over the art of maintaining judicial rulings. Thus, one of the recommendations of this study is the need to include the science of judicial logic in the curricula of law teaching, with the need to pay attention to the art of maintaining judicial rulings.
\end{abstract}

Keywords: Judicial reasoning, logical reasoning, conditioning, corruption in reasoning, standard reasoning.

DOI: $10.7176 / \mathrm{JLPG} / 113-05$

Publication date:September $30^{\text {th }} 2021$

\section{Introduction}

It is a true that securing criminal justice lies in the integrity of the criminal sentences issued by the criminal judiciary. This is clear in the criminal sentences which is rendered by the conviction because of its great and serious impact on human life and freedom to the extent that it confiscates human's freedom. Therefore, it is necessary to pay attention to the penal sentence and surround it with special care.

Naturally, the criminal judge's task in sentencing is not only limited to balance evidence, but it is also a technical and logical act in which the criminal judge pays an organized, intellectual, logical and tiring effort that takes into account all the specificities of the criminal case. Moreover, there is no doubt that this work or effort by the judge is called by law's commentators "judicial logic" emanating from judicial thinking based on logical rules and scientific approaches that reveal the relative links between facts and legal models. Judicial logic thus plays an important role in ensuring the integrity and security of criminal sentences with high-precision quality that convinces opponents and public opinion.

There is no doubt that judicial thought tends to consider criminal sentence, along with its legal construction, as a logical constructive approach that expresses a certain logic, which is the logic of justice that in turn reveals the objective and realistic judicial truth logically and publicly.

\subsection{The importance of the research:}

Despite its distinct importance in the criminal judiciary, the subject of judicial logic and its impact on the quality of criminal sentences did not receive the necessary attention from the jurisprudence of the procedural law; particularly since judicial logic is one of the most important guarantees in the criminal sentences issued by judges. It is a manifestation of their doing of what they have to do of search and careful consideration duty to know the truth that they declare from what they judge of cases. With judicial logic only, judges are safe from tyranny and control, because it is such as an excuse of what they see and present to opponents and the public. In addition to that, by judicial logic judges can ignore the uncertainty and doubt that may come in minds and guard everyone to their justice confidently. This is because modern criminal judiciary follows the rules of the scientific approach that leads to the truth and relies on certain principles leading to the right results.

\subsection{Research issue}

The issue of research is to figure out the role and status of the judicial logic associated with judicial thinking and based on the scientific approach in ensuring the quality and integrity of criminal sentences from any defect. Within that, it is necessary to know how the criminal judge deals with the requirements and data of judicial logic and how judge uses the methods of judicial inference? Also, we shall study the reality of the relationship between judicial logic and legal rules in the judicial application phase and the imposition of the rule of law on established facts. Furthermore, attempting to reveal the monitoring role of the Cassation Court (Court of Law) regarding the application of the law to the facts obtained from the evidence of the case and the integrity of the judicial logic for the purposes of the quality of criminal sentences.

\subsection{Research approach}

Naturally, judicial logic is crystallized in a practical and judicial nature, especially since the judge's work is a mental one with a logical mentality that combines the understanding of reality, law and logic to determine the emotional conviction objectively. Therefore, the appropriate approach to this research is the synthetic analytical 
approach, through the analysis of scientific material of jurisprudence and legal texts related to the subject of the research and analysis of its objective and theoretical aspects; in addition to the installation of logical facts to reach correct scientific results as the work of a judge is based on a combination of facts and law.

For the impact of judicial logic on the quality of criminal sentences to take shape, the logical division of this research requires that it shall be divided into the following two topics:

First topic: concept of judicial logic and methods of inference.

Second topic: rules of the application of judicial logic and judicial applications to accommodate reality and law.

\section{Concept of judicial logic and methods of inference}

In principle, logic has a profound impact on legal sciences in general and criminal laws in particular, which requires highlighting the concept of judicial logic in this context and revealing the approaches of judicial logic as a criterion for inferring it in the underline of the emotional conviction of the criminal judge. In order for judicial logic and approaches to be clarified, the concept of judicial logic must be addressed as a first requirement and the methods of logical inference as a second requirement.

\subsection{The concept of judicial logic}

Logic in general is science that builds the general rules of sound thinking regardless of the topics addressed by thinking ${ }^{1}$.

Ibn Sina defines logic as the industry of theory that leads us to the right limits and the common measurement, which is called proof. Others define it as science that protects from falling in mistakes in thinking, so it is said that a person is logical which means that he/she thinks properly. So, logic seeks to achieve the agreement of the mind with itself ${ }^{2}$.

Aristotle considers that logical reasoning (Syllogisms) is the logical conclusion (Raisonnement) which is based on certain introductions that lead logical necessity to a particular result ${ }^{3}$.

The common example here is:

A big issue: every human being is mortal.

A small issue: Socrates is a human being.

Result: Socrates is mortal.

Imam Al-Ghazali is credited with taking logic out of philosophy issues to the scientific style ${ }^{4}$, where he says, "whoever has no knowledge of logic does not document his knowledge". Modern thought tends to consider the judicial sentencing as logically constructive to the extent that others say that sentencing is logic ${ }^{5}$.

It can be said that judicial logic is about the interpretation of legal rules within a practical framework towards to a particular case. Where its movement focuses on different facts and the choice of what is necessary of them for the purposes of sentencing. To be able to do so, judges shall consider the facts provided to them and then analyze the initial elements overlapping in their composition and circumstances surrounding them. Therefore, judge can choose the law which shall be applied and arrange its legal implications ${ }^{6}$.

Therefore, judicial logic is a mental process or intellectual activity through which the criminal judge verifies the criminal incident on the side of the accused, uses it to impose a sentence of law on it and obliges the judge in the form of logical reasoning methods ${ }^{7}$.

Naturally, judge does not reach the conclusion in his/her judgment in an automatic manner, but rather performs successive mental processes. These processes require to be governed by the rules of logic so that the reasons for the judgment that the judge's intellectual and mental activity have reached are convincing to the opponents, public opinion, and higher courts ${ }^{8}$.

Since the judge in his/her judicial work applies the rules of logic science to reach a result that is identical or consistent with the principles of reason and proper logic. By doing so judge applies judicial art, given the methodology provided by logic science for clear and correct thinking, so that the judge is aware of the nature of

\footnotetext{
${ }^{1}$ Dr. Abdul Rahman Tawfiq: Lectures printed in the judicial logic of students of the Jordanian Judicial Institute, a study of a comparative jurisprudence coupled with the rulings of the judiciary of 1994, p. 7.

${ }^{2}$ Dr. Mohammed Ali Al-Kik: The Origins of Criminal Sentencing in the Light of Jurisprudence and Justice, Publisher of the Radiation Library, Alexandria, 1988, p. 288

${ }^{3}$ Abdul Maqal Al-Saedi: Renewal of Logic, Third Edition, Library of Literature without a Year for Publication, p. 4 and 7 , in the same sense Ahmed Fathi Sorour, Criminal Veto, Dar al-Shorouk 2003, p. 265.

${ }^{4}$ Abu Hamed al-Ghazali: The Logic of Philosophers' Eagerness called "The Standard of Science" achieved Suleiman Dunya, Arab Munitions, Egypt, Dar al-Ma'ad, 1901, p. 69.

${ }^{5}$ Dr. Ahmed Fathi Sorour: Mediator in the Code of Criminal Procedure, Volume 1 and 2, Fourth Edition, 1984, p. 167.

${ }^{6}$ Dr. Hatham Hassan Musa Bakar: The Criminal Judge's Authority to Assess Punishment and Precautionary Measures, Publisher Knowledge Facility, Alexandria, 2002, p. 102.

${ }^{7}$ Muhammad Ali Sweilm: Adaptation in Criminal Materials, University Publications House, 2005, p. 116.

${ }^{8}$ Youssef Mohamed Al-Masaroa: The provisions are in accordance with the Law on the Origins of Civil Trials, Publisher of the International Scientific House, And The Culture House for Publishing and Distribution, First Edition, 2002, p. 255.
} 
his/her rules as well as subjecting his/her emotions to his/her serious awareness of the logic of art ${ }^{1}$.

Research of the concept of judicial logic leads us to address the following sections:

Section 1: Logical Inference

Inference in jurisprudence means to request evidence. Inference in logic is the sequence of several judgments that are arranged among each other so that the latter is compatible and shall depend on the former. Since each inference is a mental act consisting of successive judgments, if some of them are violated, then other judgments shall replace them. Obviously, this judgment is not truthful unless its introductions are true ${ }^{2}$.

Logical reasoning is the basic tool that standardizes means (in law refers to means of proof) and assembles them as a single package to draw conclusions.

Not surprisingly, logical reasoning is based on several elements and controls that can be reported as follows:

First: premise/s in which the validity of the result can be inferred.

Second: a result of this premise/s.

Third: a logical relationship that binds the premises if they are multiple or links them jointly to the result, as necessary.

Fourth: the human principles and laws on which the mind depends in its movement and transition from premise/s to the result ${ }^{3}$.

An example of evidentiary laws, "axioms of logic," is the law of non-contradiction. The contradiction destroys causes and encourages them to contradict each other. Therefore, whenever the reasons conflict with logic, a radical conflict, such as if the judge demonstrates the innocence of the accused and then decides to convict him, so the logic becomes missing the premises that support it. So, it is not suitable, for example, for the court to mention the fact of the case on two opposing images or to be based on contradictory evidence without explanation for this contradiction ${ }^{4}$.

It must be pointed out that the reasoning is either correct or wrong, but the logic study is limited to the correct inferences, so it is necessary to move to the study of judicial inference in this context of the research.

Section Two: Judicial Reasoning

Of course, judicial logic is accompanied by a judicial reasoning, and it refers to the work carried out by the judge in the context of extracting a certain conclusion from the major premise "law" and the minor premise "facts" to reach to a just decision that is neither judged nor acknowledged ${ }^{5}$.

Normally, the essence of inference is related to the judicial process that aims to reach a sufficient proof of the validity of the conclusion it concluded in its assessment of the case fact and its evidence, based on rational principles and logical controls ${ }^{6}$.

Therefore, we find that the judicial reasoning takes a practical character that the judge uses when practicing his judicial work, starting with confronting the overlapping and intertwining facts to prove and crystallize them in the facts of the judicial decision of the case.

Thus, the judicial inference is linked to the judicial proof, so whoever claims the fact shall prove it ${ }^{7}$.

The judge must observe certain rules when examining facts and evidences, when adapting these facts, and applying the rule of law to them. Therefore, within the framework of that, the judge makes three types of inference:

First: Dialectical reasoning for convincing the evidence.

Second: Inductive reasoning to note the facts on which the evidence of the case is based.

Third: Deductive reasoning to reach a specific conclusion in light of the facts that have been established ${ }^{8}$.

There is no doubt that judicial inference is based on methods and foundations that must be used by the criminal judge to build his/her judgment on rational and logical foundations. Thus, we find that the use of analogical inference (a major premise "law" + a minor premise "the facts" = the result of a "logical judicial decision") is the basic model of inference, which is a tool for providing conclusive proof in addition to presenting arguments ${ }^{9}$. It can be said that the criminal judge is obligated to present proof of the validity of the findings he/she has

\footnotetext{
${ }^{1}$ Mohammed Fahim Darwish: The Art of Justice between Theory and Practice, Civil and Criminal Trials, First Edition, Zahra Presses for Arab Media, 2007, p. 263.

${ }^{2}$ Muhammad Ali Al-Kik: op. cit., p. 291.

${ }^{3}$ Dr. Muhammad Ali Al-Keik: The Origins of Causing Criminal Judgments in the Light of Jurisprudence and Judiciary, op. cit., p. 291.

${ }^{4}$ Dr. Raouf Obeid: Controls for Causing Criminal Judgments, Arab Thought House, third edition 1986, p. 198.

${ }^{5}$ Dr. Hatem Hassan Musa Bakkar: The authority of the criminal judge in assessing punishment and precautionary measures, op. cit., p. 102 and 103 .

${ }^{6}$ Muhammad Jamal al-Din Hegazy: The Court of Cassation's censorship about the criminal case, Al-Fath for printing and publishing, Cairo 2001, p.

${ }^{7}$ Ahmed Habib Al-Sammak: The Presumption of Innocence and Its Consequences, Journal of Law and Economics, Cairo University, No. 67, 1997, p. 272

${ }^{8}$ Youssef Al-Masarweh: Causing Judgments according to the Code of Civil Procedures, the publisher of the International Scientific House and Dar Al-Thaqafa for Publishing and Distribution, First Edition, 2002, p. 265.

${ }_{9}^{9}$ Azmi Abdel Fattah: Reasoning Judgments and Judges' Actions in Civil and Commercial Matters, Fourth Edition, Cairo, Dar Al-Nahda AlArabiya, 2006, p. 249
} 
reached, which is known as evidence of the penal judgment. This proof is based on three elements, which are as follows:

1- The fact of the case that calls for proof.

2- Arguments and linking them to the case fact.

3- The manifestations of proof or the so-called logical link between the fact and the arguments.

Accordingly, it can be said that the criminal judgment is the sign indicating the final cutoff of the judicial inference made by the criminal judge ${ }^{1}$. Whenever this inference contradicts the principles of reason and common sense, the penal judgment is tainted by the defect of corruption in inference.

Therefore, the facts must be approached with the law to reach a conclusion that does not carry the flaw of mistake. Therefore, it is necessary to address the approach between facts and the law through judicial logic.

The third branch: approaching reality and law to the criminal case.

There is no doubt that the criminal case brought before the criminal judge raises a mixture of reality and law, and the judge works in the framework of two parts (a realistic part) and (a legal part), thus the judge uses judicial inference to logically install the two parts, and it is necessary to study these two areas.

First: the field of facts

The facts in the legal sense are the source of the right claimed before the judiciary, which is the legal act or the legal event that established this right and which the plaintiff is required to prove ${ }^{2}$.

However, the incident in the field of criminal law is the incident of the crime committed in the external world and presented to the judge, which is called the procedural event.

The incident in the art of criminal justice is that which occurs in the realm of reality and leads to something ${ }^{3}$.

Second: Factual Elements in the Criminal Law

The facts that are relied upon in criminal law are the facts whose legal elements are complete, represented by the material element and the moral element, the "essential elements of the incident".

A- The material element.

Naturally, the material element is represented in the criminal activity carried out by the perpetrator, which consists of the following three elements:

1. Criminal behavior.

2. The result.

3. The causal relationship that links the behavior to the result.

Thus, the criminal behavior is obtained through the activity of the offender with the intent of achieving the result ${ }^{4}$ and it is equal in that whether crime's result is positive or negative ${ }^{5}$ and it is legally recognized that if the result is not achieved in its physical forms; the crime stops when the attempt is realized by starting the execution without the result being achieved for a reason outside the will of the offender.

B - The moral element:

This element is based on:

1 - Knowledge.

2- A sinful will.

The sinful will is the link between the crime as a material fact that has an external entity and the person from whom it was issued, whom the law considers responsible for this crime and describes him as an offender ${ }^{6}$.

We find that the circumstances surrounding the commission of the incident, the subject of the crime, do not become secondary elements. It modifies the effects of the crime by affirmative or negative after completing the elements of the crime.

The criminal judge, in his/her review of the legal elements of the crime, the subject of the case, does not apply those legal elements except as required by the events so that his/her application of the law is sound.

Third: the field of law

Within the framework of applying the judicial logic and reaching the major premise (the model legal rule) that is applied to the minor premise (the committed incident), the criminal judge reaches the decisive opinion in the case brought before him $^{7}$.

\footnotetext{
${ }^{1}$ Azmi Abdel-Fattah: Causing judgments and judges' actions in civil and commercial matters, op. cit., p. 331.

${ }^{2}$ In this sense, Abd al-Razzaq al-Sanhouri: The Mediator in Explaining the New Civil Law, Part Two, Theory of Commitment in General, to Prove the Effects of Evidence, Third Edition, Beirut, Al-Halabi Publications, p. 1 and 2.

${ }^{3}$ Ali Mahmoud Ali Hammouda: The Logical Origins of Understanding Reality and Law in Criminal Cases, Dar Al-Nahda Al-Arabiya for Publishing and Distribution, 2003, p. 14.

${ }^{4}$ Abdel-Azim Morsi Wazir: Explanation of the Penal Code, General Section, Part One, General Theory of Crime, Fourth Edition, Dar AlNahda Al-Arabiya, 2000, p. 271.

${ }^{5}$ Ali Hammouda: The Controls of Correlation Between the Facts of the Criminal Case and the Judgment Issued in it, First Edition, Cairo, Dar Al-Nahda Al-Arabiya, 2007, p. 16

${ }^{6}$ Reda Farag: Explanation of the Penal Code, General Provisions for Crime, Second Edition, Algeria, National Company for Publishing and Distribution, 1976, p. 363.

${ }^{7}$ Ali Mahmoud Ali Hammouda: Logical Origins of Understanding Reality and Law in Criminal Cases, op. cit., p. 93.
} 
Thus, the two elements of the criminal case are the reality and the law, and the precise definition of the facts for the purpose of creating the model text according to the judicial logic is the key to the sound solution of the case. To reach to that, the criminal judge must use the rules of judicial logic to collect the facts of the case, in another sense, understanding (the facts and the circumstances of the case). Accordingly, judicial logic is used to digest the facts, which is known as the interpretation of criminal texts. When applying the law to the facts and drawing conclusions, the judge has decided on the case using the judicial inference method, and thus it is possible to move to methods of inference.

\section{2 methods of judicial reasoning}

While presenting the criminal case to the criminal judge, he/she automatically exercises a degree of dialectical reasoning that is based on interpretation between the elements of material facts that enter into the composition of the procedural model. The judge studies the persuasive evidences that participate in reaching the conclusion, whether these evidences are (evidences of proof or denial). In this context, the judge conducts researching in the nature of the evidences and the associated equivalence, support and use of the authority to accept and appreciate the evidences so that there must be complete agreement between all the elements of logical reasoning in order to reach the truth ${ }^{1}$.

Accordingly, it is necessary to understand the essence of the methods of judicial reasoning that the criminal judge uses during the consideration of the criminal case, as this can be done by addressing the methods of analogy, deduction and induction, also it is necessary to examine the controls of judicial reasoning through the coming parts.

Part one: analogical inference

Judicial analogy plays an important role in the judicial logic of the legal aspect, especially as it helps to determine the correct legal adaptation of the established fact, in other words highlighting realistic cases that fall under the law.

Normally, the effect of this type of inference is considered an abstract logical inference based on a purely mathematical method in the logical interpretation of the legal text that applies to the incident, as it is a judicial logic related to the law.

Among the defects that were directed to this type of inference is its reliance on the legal base in terms of the text in isolation from the content, as it ignores the social reality and the social interests that are protected by law ${ }^{2}$. This inference is characterized by rigidity and is not concerned with social reality.

Part two: deductive reasoning

Deduction means the transition of thinking from the known to the unknown ${ }^{3}$. In the context of this approach, deductive thinking mainly depends on the part to reach the whole, i.e. reliance on punitive facts to reach the final result.

In this regard, it can be said that if the ascent from the incident to the law is called induction, then the descent from the general to the particular is called deduction. Deductive inference is one of the methods that the criminal judge relies on in bringing the interrelationship between the various basic elements of the case; Through deduction, the judge performs the synthesis process, whereby the final event is drawn, which in turn draws the final legal conditioning.

This branching of judicial inference is expressed by the faculty of deduction, and it can be concluded that the confirmed results that the judge draws from certain premises is a flexible mental process that leads to inevitable results. This deduction must be palatable and logical based on true facts that reach their truth by practical means and logical standards ${ }^{4}$.

Part three: Inductive Reasoning

The distinct characteristic of inference is accuracy, as thoughts move between three stages:

Stage one: distinguishing premises.

Stage two: methods' works (analogy, deduction, induction).

Stage three: Reaching the result.

Inference by induction is represented by the transfer of thought from knowledge through a series of identical facts to knowledge in all cases, meaning that it is the transfer of thought from judging some members of the species to judging the same species ${ }^{5}$.

In the criminal field, the method of induction depends on observation and experiment. It is a scientific method that depends on the selection of tangible material facts to determine who enters into the criminal model of the

\footnotetext{
${ }^{1}$ Muhammad Jamal al-Din Muhammad Hijazi: Court of Cassation oversight of the subject matter of the criminal case, op. cit., p. 400

${ }^{2}$ Dr. Ahmed Fathi Sorour: Criminal Cassation, op. cit., p. 276.

${ }^{3}$ Mahmoud Yaqoubi: Lessons of formal logic, University Press Office, 1993, p. 181

${ }^{4}$ Muhammad Fahim Darwish: The Art of Judgment Between Theory and Practice, op. cit. p. 298 and 299.

${ }^{5}$ Mahmoud Yaqubi: Lessons of Formative Logic, op. cit., p. 6.
} 
criminal incident in the criminal case ${ }^{1}$.

Thereby, the criminal judge conducts an induction process of the overlapping, intertwined and scattered material facts to know and determine which facts fall within the major premise of inference; And that is through judge's criminal observations of the facts through the evidence presented to him/her, sorting and categorizing them in a way that highlights their common characteristics.

Normally, in the criminal field, the facts are multiple, overlap and intertwine among themselves, which requires identifying the basic elements of the committed incident in order to include it in the legal model of the crime, this can only be achieved by examining and scrutinizing these facts through inductive reasoning and its controls.

Part Four: Judicial Reasoning Controls

At this point, a question arises about the controls governing the validity of judicial inference. Are there legal controls that can be relied upon in this context?

In fact, we notice that most of the procedural legislation, including the Jordanian procedural legislation, did not include any legal texts controlling the judicial reasoning, as these legislations left the task of defining the controls for the jurisprudential and judicial activity which in turn illustrates these controls as follows:

First: The evidence must be valid for the judges to carry out.

The validity of criminal judgments is required to be based on legal evidence that leads to conviction, and that the court must indicate the fact that it has reached and demonstrate the reasons leading to $\mathrm{it}^{2}$. Jordanian Court of Cassation has decided that ignoring the evidence proving the crime and not discussing it and drawing conclusions contrary to what was stated in it flawed the ruling on the corruption of reasoning ${ }^{3}$. The Jordanian Court of Cassation also decided that the following conditions must be stipulated for the confession to be considered an element of reasoning in criminal matters:

1 - It must be issued by a person with legal capacity.

2- It must be of free will and not coerced.

3- To be in accordance with the truth and reality 4

Second: the assessment must be reasonable and acceptable

Jurisprudence and the judiciary have established that the authority of the subject court to verify the fact and assess its evidence is not absolute, but rather restricted to its estimation in that being characterized by logic, which was expressed by the Court of Cassation that the estimation should be justifiable and acceptable. So, the estimation is logical when inspired by the principles and logical controls that the premises lead to the conclusion reached by the judgment. Therefore, the Court of Cassation has the right to supervise the trial court in its determination of evidence if it leads to unjustifiable results.

In this context, the Court of Cassation decided that the High Criminal Court does not have absolute authority to assess and understand the evidence if this evidence is not rationally plausible and based on the evidence in the case documents ${ }^{5}$. We also find from the Court of Cassation that: If the submitted evidences lead to the conclusion that the court has reached and that this conclusion was drawn by the court in conclusion (plausible and acceptable), then what is based on this is that the appealed judgment is in accordance with the provisions of law.

Third: reasons are based on fixed evidences in the case documents.

The judge's sentence must be based on evidences derived from the case papers. In other words, judge's conviction should be derived from the litigation procedures, so he/she bases his judgment on the evidence established in the case file, as he/she is required to indicate from where he/she derived the reasons for the judgment $^{6}$

Among the judges of the Court of Cassation in this regard: It is decided by jurisprudence and law that the trial court is fully free to examine the statements of witnesses to take from them what they are comfortable with and to extract from the evidences and the elements before it on the basis of correct research of the incident of the case according to its conviction and to avoid what contradicts it of images that were not convinced of their validity as long as their extraction is justified and based on legally acceptable evidences, in logic and reason, and it has its proven origin in the documents?

Thus, we find that what is established by the Court of Cassation is that the Court of First Instance is not obligated to justify its lack of conviction with a certain evidence. Also, it is sufficient for it to be subtracted from the list of the evidence presented and not to rely on it in forming its conviction. Court of Cassation has no control over it in this unless that evidence is fictitious and illegal, it does not have an origin in the case documents, or it

\footnotetext{
${ }^{1}$ Muhammad Jamal al-Din Muhammad Hijazi: Oversight of the Court of Cassation on the subject of the criminal case, p. 401

2 Penalty cassation No. (672/97) Attorney Association Journal, issue No. 2 and 4 of 1998, p. 1024.

${ }^{3}$ Penalty Cassation No. (767/97 Attorney Association Journal, issue No. 2 and 4 of 1998, p.

${ }^{4}$ Penalty Cassation No. (732/2003) dated 7/29/2003, Adalah Publications.

${ }^{5}$ Penalty Cassation No. (754/97) Attorney Association Journal, issue No. 3 and 4 of 1998, p. 1033.

${ }^{6}$ Youssef Al-Masarweh: op. cit., p. 218.

${ }^{7}$ Discrimination, Penalty No. 39/99, Attorney Association Journal, issue No. 9 and 10 of 1999, p. 3304.
} 
does not lead to the reached conclusion ${ }^{1}$.

In sum, the judicial reasoning in the judgment is based on evidence taken from the case documents. If it turns out that the judge has based the reasons for his/her judgment on evidences that have no firm origin in the case documents, judges' judgment is flawed with the defect of causation and within the scope of these facts, the following three important rules must be referred to:

A- Rule of establishing evidence in the case documents

Article (148/1) of the Code of Criminal Procedure states that (a judge may only rely on evidence that was presented during the trial and in which the litigants are openly discussed).

Normally, the judge forms his/her belief in the light of what his/her conscience is comfortable with and through the evidence in the case documents, where the judge is not permitted to form his belief by mere imagination or guesswork, especially since penal judgments are based on certainty and not on doubt and speculation. Also, the evidence derived from the documents is in the place of the litigants, discussing and refuting it ${ }^{2}$.

It goes without saying that the evidence is identical to what was stated in the documents, which is required to refer to the case file and its documents. In the event that the court relies on fictitious evidences that do not exist in the case documents, this will lead to judgment annulment.

b- Rule of inadmissibility of reliance on personal information

Article (3) of the Jordanian Evidences Law states that: (a judge dose not has the right to rule with his/her personal knowledge) because establishing judicial rulings on personal information of judges means wasting several basic principles in trials, including the principle of oral arguments, the principle of respect for the rights of the defense, and the principle that it is not permissible for the judge to be both a judge and a witness at the same time. Judge's personal information should not be confused with public information that anyone can be familiar with, because judge has the right to make his/her judgment based on this type of information ${ }^{3}$.

C- Rule of prohibition of reliance on defective evidence

The freedom of the judge to form his/her conviction and belief based on the evidence presented in the case is conditional on that this evidence is valid and legitimate. But if the evidence is illegitimate and incorrect, then the judgment based on such evidence is invalid and defective ${ }^{4}$, the invalid evidence cannot be relied upon. The court may not rely on it in its judgment ${ }^{5}$.

\section{Rules for applying judicial logic to accommodate reality and law}

Naturally, mental activity carried out by the judge is considered a mental activity based on the principles of judicial reasoning to assimilate two elements (reality and law), namely (the material of the judge's mental activity).

In order for the criminal judge's jurisprudence to crystallize, and his/her decision to be justifiable and compatible with the principles of reason and sound logic, judge must verify the evidence of the element of reality (understanding of reality) as well as (understanding of law) as the goal of judicial work. Also, judge must go through the philosophy of law to reveal a logical conclusion based on sound logic.

In order to achieve this and to clarify the elements of the rules of judicial logic, this topic must be divided into the following requirements:

The first requirement: understanding the surrounding facts and circumstances.

The second requirement: the proper legal characterization of case's facts.

The third requirement: interpretation and application of criminal legal texts to the facts.

\section{1 understanding the surrounding facts and circumstances}

When understanding the facts and collecting them as they happened in the real world, it is correct to apply the legal texts to them, provided that these facts are the real facts ${ }^{6}$. Therefore, this means that the judge applies the law correctly ${ }^{7}$. In the context of the judge's use of judicial reasoning, he/she must use the faculty of awareness, which is the mental ability with which the judge realizes the truth of the incident, in addition to his/her sufficient and justifiable understanding of the evidence in the case as means of proving the incident if it is valid to apply the legal text to it $^{8}$.

In this context, it can be said that if the understanding of reality is flawed or insufficient awareness, it will inevitably lead to a wrong judgment and therefore, this matter leads to an error in the application of the law and

\footnotetext{
${ }^{1}$ Penalty Cassation No. (521/99) Judicial Journal, Third Year, Issue Seven, 1999, p.

${ }^{2}$ Dr. Muhammad Ali Al-Kik: Causing the Criminal Judgments, op. cit., p. 270

${ }^{3}$ Dr. Muhammad Ali Al-Kik: op. cit., p. 275.

${ }^{4}$ Abd al-Rahman Tawfiq: Lectures on Judicial Logic, op. cit., p. 108.

${ }^{5}$ Dr. Muhammad Ali Al-Kik: op. cit., p. 278.

${ }^{6}$ Ali Mahmoud Ali Hammouda: The general theory of causation of the criminal judgment in its various stages, a comparative study, second edition, 2003, p. 182.

${ }^{7}$ Ramses Behnam: Judicial Psychology, Knowledge Foundation in Alexandria, p. 32

${ }^{8}$ Muhammad Zaki Abu Amer: The Imperfection of Error in the Criminal Judgment, University Press, 1985, pp. 287 and 288.
} 
makes the judgment tainted by error and subject to annulment and terminate by the higher courts.

We would like to refer to what the jurists have indicated regarding many of the reasons that lead to a false awareness of the true reality, which can be stated as follows:

First: Rooting without analysis

This is because the judge is sentencing more than he/she realizes ${ }^{1}$ by believing and thinking that all the facts are similar and identical, knowing that the incident presented to the judge is a particular and distinct fact.

Second: Adherence to intellectual habits that are established in the mind

What is meant by that is to pay attention to the physical appearance, such as if the witness is ugly or wears shabby clothes, even though what he/she testified about is at the heart of the truth.

Third: The judge placed himself in the position of the accused or the victim

This is not acceptable; the judge shall not compare himself with one of the parties of the case, and he/she must be impartial in that.

Fourth: The judge is affected by his/her personal work or own experiences

Normally, this matter is based on the famous rule that the judge does not sentence with his/her personal knowledge ${ }^{2}$

In sum, the judge must be fully aware of all aspects of the incident, which is the correct way to describe it with the correct description in order to determine the applicable legal text for it.

\subsection{The proper legal characterization of the case facts}

One of the most accurate and difficult judicial issues is legal characterization of facts, especially since the facts may be subject to several legal characterizations ${ }^{3}$.

It can be said that the general meaning of the term criminal conditioning is the legal description that the legislator gives to the criminal act committed by the offender.

Therefore, the legal characterization is crystallized in giving the judge the legal description that the facts produced in the case deserve after examining them, understanding them correctly and justifiably, discussing and proving them in the prescribed ways ${ }^{4}$.

Characterization is the legal description of the incident as proven in the world of reality ${ }^{5}$.

Normally, legal characterization goes through stages as a judicial artwork.

Section one: The stages of legal characterization

Legal characterization as a mental activity goes through several stages that can be listed as follows:

The first stage: probabilistic characterization

This stage is related to the criminal judge's understanding of the legal rule, whether it is in the aspect of the sum of elements that legislator imagined and formulated in a legal model as a legal rule or in its understanding of their effect ${ }^{6}$.

In this context, the judge will search for the legal rule or possible legal text from the sum of the adaptations found in the Penal Code.

This characterization is not at this stage "probabilistic characterization ".

The second stage: the initial characterization stage

At this stage, the role of the judge of the legal rule emerges within the framework of identifying its components and elements, by viewing the facts of the case, as the judge at this stage sorts out more than one legal rule ${ }^{7}$ and it is only necessary to perform logical physical matching by bringing down the legal judgment on the facts in question to reach the third and last stage.

At this stage, the criminal judge applies the proper legal description to the established facts of the case. In this context, a material match is made between the judgment of law and the model legal template on the second incident, so that the incident will has a legal description ${ }^{8}$.

The second section: the technique of legal characterization

It is not surprising that the process of legal characterization is considered a technical process based on the fact that the legal description that is described as the act by the criminal judge is inclusive of all the material and legal

\footnotetext{
${ }^{1}$ Ramses Behnam: Judicial Psychology, Mansha'at al-Maaref in Alexandria, 2000, p. 34.

${ }^{2}$ Ramses Behnam: op. cit., p. 34-39.

${ }^{3}$ Hamid Al-Saadi and Muhammad Ramadan Barah: Legal Conditioning in Criminal Matters, a comparative study, Fang Universities Complex Publications, 1989, pp. 23-24.

${ }^{4}$ Ali Masoud Muhammad: The Judge and the Realistic Elements of Civil Conflict, First Edition, Libya, Talha Bin Obaid Allah Center for Printing, Publishing and Distribution, Thursday 2006, p. 299.

${ }^{5}$ Ali Mahmoud Ali Hammouda: Logical Principles for Understanding Reality and Law in Criminal Cases, op. cit., pg. 97.

${ }^{6}$ Ahmed Mahmoud Saad: The concept of the discretionary power of the civil judge (its nature, controls, and applications), first edition, Dar Al-Nahda Al-Arabiya, 1988, pp. 465-566.

${ }^{7}$ Ahmed Mahmoud Saad: op. cit., pg. 468.

${ }^{8}$ It is noted that there is a great overlap and correlation between legal conditioning and legal description, but what matters to us is the mechanisms and tools that the judge uses to give the proper legal description.
} 
elements of the incident and the surrounding circumstances. Also, the technique of characterization obliges the judge to make a mental reasoning through which he/she studies all the particles of the incident in the light of the evidences presented in the case and then approaches the criminal legal template that corresponds to it and forms a legal relationship between the incident and the legal text subject to it, which calls for a reference in the judgment to that relationship between the incident and the legal text, that is, the elements that constitute the committed criminal behavior and the applicable legal text must be reviewed. It can be referred to the statement of one of the jurists crystallizing the true meaning of characterization, where he says: (characterization is the pulse of life in relation to the law) ${ }^{1}$.

\subsection{Interpretation and application of criminal legal texts to the facts}

Judge's work does not prevent him/her to understand reality and law. Rather, the judge must study the law deeply to stand and reveal the protected interests and rights, because the law came to protect those interests and rights, and it is natural that the judge faces difficulties and ambiguity when he/she interprets some legal texts on the facts presented to him/ $/ \mathrm{her}^{2}$.

Therefore, the judge must understand the words and premises of the legal texts before applying them. Since there are general provisions that are applicable to all texts of the law while others are limited to some texts ${ }^{3}$. Therefore, legal logic has historically been linked to interpretation.

Judicial logic is used by the criminal judge to interpret and apply legal rules to reach a logical conclusion that convinces opponents and public opinion ${ }^{4}$.

Interpretation means to clarify the most insidious terms of texts and to clarify the ambiguities of them ${ }^{5}$, as well as to transfer the legal rule from the scope of abstraction to the field of practical application ${ }^{6}$. In this context it is necessary to identify the nature of the use of judicial reasoning to change the law and the logical structure arises from that for penal sentencing and the art of drafting penal rulings associated with it.

Section one: Using judicial reasoning to interpret the law

In this context, a distinction must be made between the clear text and the ambiguous text regarding the facts presented before the criminal judge.

First: the case of clear text

Naturally, the clear text does not require a mental effort on the part of the judge so that it can be applied to the incident in question. Clarity means both words and meanings. The judge must adhere to the apparent meaning of the text based on the legal rule: there is no jurisprudence in the applicable text resource.

Second: the case of ambiguity of the text

In this regard, the criminal judge must make an effort in interpretation in order to reach the significance of the words and meanings, will of the legislator, purpose behind the text, and the nature of the interest with penal protection $^{7}$.

In order to reach the will of the legislator, "purpose of interpretation" by logical interpretation, the criminal judge relies on the following:

1- Seeking the help of the protected interest to reach an explanation of the reason for the text. The reason for this is that all criminal texts refer to behaviors which law has offended aiming to protect specific interests and rights, whether public or private, of interest to society and individuals.

2- The use of the preparatory works for the laws. In the event that the judge is unable to remove the ambiguity surrounding the criminal text, he/she can return to the origin of the text by referring to the preparatory work for it ${ }^{8}$.

The second branch: logical structure of criminal judgment

There is no doubt that the criminal judgment is a logical and linguistic construct. Logic directs the mind towards searching for the truth. Logic is an art because it aims to maintain ideas in an orderly manner based on knowledge and experience.

In this connection, the criminal judge substantially proves the facts subject of the case (subjective and objective assessment. Then the judge searches for the applicable legal model (legal characterization or the so-called in

\footnotetext{
${ }^{1}$ Ali Mahmoud Ali Odeh: Logical Origins of Understanding Reality and Law in Criminal Cases, op. cit., p. 99.

${ }^{2}$ Barch Suleiman: Explanation of the Algerian Penal Code, Part One, The Legitimacy of Criminalization, Batna, Al-Shehab Press, 1992, p. 29.

${ }^{3}$ Dr. Ahmed Fathi Sorour: Constitutional Criminal Law, Dar Al-Shorouk, 2006, p. 99.

${ }^{4}$ Azmi Abdel-Fattah: Developments in the Kuwaiti Pleadings Law and complementary laws in the field of causation of judgments and the work of judges, Journal of Law, Kuwait University, No. 1, for the eighth year, 1984, p. 115.

${ }^{5}$ Sri Mahmoud Siam: Judicial Interpretation and Protection of the Procedural Rights of the Accused, Comparative Study, Dar Al-Nahda AlArabiya, p. 24

${ }^{6}$ Ahmed Fathi Sorour: The Origins of the Penal Code, General Section, The General Theory of Crime, Dar Al-Nahda Al-Arabiya, 1979, p. 69.

${ }^{7}$ In this sense, Ali Abd al-Qadir al-Qahwaji: Penal Code / General Section, University House, 2000, p. 99.

${ }^{8}$ Ali Mahmoud Ali Hammouda: Logical Foundations for Understanding Reality and Law in the Criminal Case, op. cit., pg. 113.
} 
reality: legal assessment) and then deeply understands the law by interpreting the criminal texts to reach the most dangerous stages of the judicial process, which is material matching between the physical incident and the legal model incident (the legal text) on the basis of which the crime is established and attributed to the perpetrators. In this context, it is based on logical means known as judicial inference with its various approaches ${ }^{1}$.

Thus, the judge uses the rules of judicial logic of induction, deduction and conclusion to conclude with the desired truth, which is the judicial truth that is within two assumptions:

1 - Certainty and assertion in the event of a conviction judgment.

2- Lack of evidence at all, insufficient evidences, or suspicion of proof evidences in the event of a judgment of acquittal.

First: Certainty and assertion in the event of a conviction judgment.

The purpose of the criminal case is to reach the truth that can be reached through a refraining based on certainty and assertion, not on speculation and guess.

In order to ensure access to a correct criminal judgment that is free of mistakes, the criminal judge must be rational in his/her thinking and logical in his/her inferences in order for his/her conviction to be based on a true correspondence between the facts of the crime between them and the law. This will only be possible by following a scientific approach based on the use of logical rules to understand reality and law ${ }^{2}$.

Second: Lack of evidence, insufficient evidences, or suspicion of proof evidences in the event of a judgment of acquittal.

The verdict of acquittal does not require that the judge's conviction reach the point of assertion and certainty. Rather, it is sufficient for the judge to doubt the validity of the attribution of the crime to the accused to adjudicate acquittal based on the basis of suspicion to be interpreted in favor of the accused.

However, the judge is bound by an essential condition, which is that the judge states in his/her judgment that he/she examined all case's evidences and doubted the elements of the accusation ${ }^{3}$. In other words, the evidences in terms of its insufficiency, inconsistency or not reaching the level of conviction because they are mere suspicions.

Since the truth is the judge's stray and his/her desired goal, what is meant by it is the actual judicial truth, and it comes through two types of understanding within the mental activity of the criminal judge, which are:

The first type: understanding reality, which is the result of what has been deduced from forensic evidences.

The second type: understanding the law, which is the rule of law in relation to these fixed facts.

The law was applied to the facts ${ }^{4}$ using the rules of judicial logic. If the judgment expresses these cycles and stages, the integrity of the penal judgment is free of any mistake and arrives at the desired truth that convinces the opponents and public opinion.

Section Three: The Art and Quality of Drafting Penal Provisions

The drafting of penal judgments is a test of the penal judge's deduction. Therefore, this deduction must be expressed in the judgment in a correct language that demonstrates and justifies the conviction of the court in its conclusion.

The importance of drafting penal provisions in a technical way is that the integrity of the law's language goes in a parallel line with the integrity of legal thought, especially since the integrity of legal thought must be expressed in clear, precise, and unambiguous language ${ }^{5}$. There is a strong link between the legal writing style and the rules of sound logic, as the judicial ruling even if it is strong by itself, its strength increases whenever it is built and formulated in a more correct and sounder way ${ }^{6}$.

Normally, the language of judicial judgment in general and criminal judgment in particular derives its strength from its clarity. The first source of this clarity is the judge's mind, as he/she understands what is to be conveyed with an accurate understanding and then expresses it clearly as it is in his/her mind ${ }^{7}$.

Therefore, great care must be taken when framing the judge's conviction in the judgment by formulating it in a technical form that clearly expresses what the judge has reached through his/her examination of the case and the evidences presented in it, and drawing conclusions from the process of material matching between the applicable legal text and the incident in question.

Perhaps the most important part on which the penal judgment is based, along with the rest of the parts, is the judgment's utterance. If the purpose of reasoning is to make the litigants feel comfortable that the judge has

\footnotetext{
${ }^{1}$ Mr. Muhammad Hassan Sharif: The General Theory of Criminal Proof: Dar Al-Nahda Al-Arabiya, Hamada Modern Press, 2002 , p. 362.

${ }^{2}$ In this sense, Ali Mahmoud Ali Hamouda: The General Theory of Causing the Criminal Judgment in its Different Phases, op. cit., p. 182.

${ }^{3}$ Ahmed Fathy Sorour: Mediator in the Criminal Procedure Law, op. cit., p. 373.

In the same sense, Hilali Abdul-Ilah Ahmed: The Truth between General and Islamic Philosophy and the Philosophy of Criminal Evidence, second edition, Dar Al-Nahda Al-Arabiya, p. 549.

${ }^{4}$ Iman Muhammad Ali Al-Jabri: The certainty of the criminal judge, a comparative study, Mansha'at al-Maaref in Alexandria, 2005 , p. 152.

${ }^{5}$ Saeed Ahmed Bayoumi: The Language of Judicial Judgment, Semantic Synthetic Study, Cairo, Al-Adab Library, 2007, p. 205.

${ }^{6}$ Abd al-Wahhab al-Ashmawi: Thoughts on the Art of Drafting Judicial Judgments, Judges Magazine, issued by the Judges Club, Issue One,

Year Nineteen, January/June 1980, p. 3.

${ }^{7}$ Saeed Ahmad Bayoumi: The Language of the Judicial Judgment, op. cit., p. 238.
} 
thought deeply about their arguments and evidence before he/she reaches the judgment's wording. Therefore, the logical reasoning must be clear, serious, not limited, and non-contradictory ${ }^{1}$.

In sum, language of judgments is characterized by ease, simplicity, and clarity. Judge before holding the pen to write the judgment, must study the case deeply, its facts and legal texts on which it is based ${ }^{2}$ and formulate the facts as they have settled in his/her conscience, through a precisely expressing of the intended meaning.

\section{Conclusion}

At the end of this study, it can be concluded that judicial logic is the important tool through which the judge derives the logical legal solution, especially since judicial logic is a controlling tool for rational thinking in order to match the real and legal truth.

Thus, judicial reasoning has a major role in ensuring the validity of criminal judgments and achieving a high quality in terms of accuracy, objectivity, and justice. Especially since judicial logic reveals to us the importance of research in determining and using the logical structure of the criminal judgment, and in how to use judicial inference methods to reach the logical result. Perhaps one of the results of this study is also that the oversight of the higher courts (appeal and cassation) over the decisions of the subject judge is an oversight of the judicial logic and methods of logical inference of analogy, induction, deduction, and the adequacy of realistic and logical reasons in addition to the rationale of legal reasons.

As for the recommendations of this study, they can be stated as follows:

First: It is necessary to include the science of logic within the curriculums of College of Law and in institutes of judiciary and law.

Second: The necessity of paying attention to the judicial language and the art of drafting judgments, and the necessity of teaching an independent subject to the art of drafting judicial judgments.

Third: The necessity of writing the reasons of judgement in a clear and strong language.

Fourth: The reasons of judgments should not be ambiguous or suspicious.

Fifth: Achieving logical consistency in the reasons for criminal judgments on one hand, and between them and the judgment pronouncement on the other hand.

Sixth: There should be no conflict or contradiction in the reasons for the ruling.

Seventh: brevity and clarity in listing the reasons.

Eighth: Staying away from the style of pre-printed formulas.

Ninth: The reasons must be valid so that the facts extracted in terms of proof or denial are justifiable and reasonable.

Tenth: Building the criminal judgment in a logical, reasonable, acceptable, realistic, and legal basis.

\section{References}

Books:

1- Abu Hamid Al-Ghazali: The Logic of the Philosophers' Incoherence called "The Standard of Knowledge" investigated by Suleiman Dunya, Dhakwar al-Arab, Egypt, Dar al-Maaref, 1901.

2- Ahmed Habib Al-Sammak: The Presumption of Innocence and its Consequences, Journal of Law and Economics, Cairo University, No. 67, 1997.

3- Ahmed Fathi Sorour: The Origins of the Penal Code, General Section, The General Theory of Crime, Dar AlNahda Al-Arabiya, 1979.

4- Dr. Ahmed Fathi Sorour: Constitutional Criminal Law, Dar Al-Shorouk, 2006.

5- Dr. Ahmed Fathy Sorour: Mediator in the Code of Criminal Procedure, Volumes I and II, Fourth Edition, 1984.

6- Dr. Ahmed Fathi Sorour, Criminal Cassation, Dar Al-Shorouk, 2003.

7- Ahmed Mahmoud Saad: The concept of the discretionary power of the civil judge (its nature, controls, and applications), first edition, Dar Al-Nahda Al-Arabiya, 1988.

8- Mr. Muhammad Hassan Sharif: The General Theory of Criminal Proof: Dar Al-Nahda Al-Arabiya, Hamada Modern Press, 2002.

9- Iman Muhammad Ali Al-Jabri: The Confirmation of the Criminal Judge, A Comparative Study, Knowledge Institute in Alexandria, 2005.

10- Barch Suleiman: Explanation of the Algerian Penal Code, Part One, The Legitimacy of Criminalization, Batna, Al-Shehab Press, 1992.

11- Dr. Hatem Hassan Musa Bakkar: The Authority of the Criminal Judge in Assessing Punishment and Precautionary Measures, Publisher Mansha'at Al-Maaref, Alexandria, 2002.

12- Hamid Al-Saadi and Muhammad Ramadan Barah: Legal Adaptation in Criminal Matters, a comparative

\footnotetext{
${ }^{1}$ Muhammad Ahmad Abu Zaid: Controls of Causation of Criminal Judgments and Controls for Drafting Criminal Judgment Data, Judges Club Applied, 2000, p. 4

${ }^{2}$ Muhammad Fahim Darwish: op. cit., pp. 42-43.
} 
study, Al-Fang Universities Complex Publications, 1989.

13- Reda Faraj: Explanation of the Penal Code, General Provisions for Crime, Second Edition, Algeria, National Company for Publishing and Distribution, 1976.

14- Ramses Behnam: Judicial Psychology, Alexandria Knowledge Foundation, 2000.

15- Dr. Raouf Obeid: Controls for Causing Criminal Judgments, Arab Thought House, third edition 1986.

16- Sri Mahmoud Siam: Judicial Interpretation and Protection of the Procedural Rights of the Accused, A Comparative Study, Dar Al-Nahda Al-Arabiya.

17- Saeed Ahmed Bayoumi: The Language of Judicial Judgment, Semantic Synthetic Study, Cairo, Arts Library, 2007.

18- Dr. Abd al-Rahman Tawfiq: printed lectures on judicial logic for students of the Jordanian Judicial Institute, a jurisprudential comparative study in conjunction with the judicial rulings of 1994.

19- Abd al-Razzaq al-Sanhouri: The mediator in explaining the new civil law, part two, commitment theory in general, to prove the effects of proof, third edition, Beirut, al-Halabi publications.

20- Abdel Azim Morsi Wazir: Explanation of the Penal Code, General Section, Part One, The General Theory of Crime, Fourth Edition, Arab Renaissance House, 2000.

21- Abdul Maqal Al-Saidi: Renewing the Science of Logic, third edition, Library of Arts without a year of publication.

22- Abd al-Wahhab al-Ashmawi: Thoughts on the Art of Drafting Judicial Judgments, Judges Magazine, issued by the Judges Club, Issue No. 19 of the nineteenth year, January/June 1980.

23- Azmi Abdel-Fattah: Causing the Judgments and the Actions of Judges in Civil and Commercial Matters, Fourth Edition, Cairo, Dar Al-Nahda Al-Arabiya, 2006.

24- Azmi Abdel-Fattah: Developments of the Kuwaiti Code of Pleadings and Complementary Laws in the Field of Causing Judgments and the Work of Judges, Journal of Law, Kuwait University, Number One, for the eighth year, 1984.

25- Ali Hammouda: Controls of Correlation between the Facts of the Criminal Case and the Judgment Issued in It, First Edition, Cairo, Dar Al-Nahda Al-Arabiya, 2007.

26- Ali Abdel Qader Al-Qahwaji: Penal Code/General Section, University House, 2000.

27- Ali Mahmoud Ali Hammouda: The Logical Origins of Understanding Reality and Law in Criminal Cases, Dar Al-Nahda Al-Arabiya for Publishing and Distribution, 2003.

28- Ali Mahmoud Ali Hammouda: The general theory of causation of criminal judgment in its various stages, a comparative study, second edition, 2003.

29- Ali Masoud Muhammad: The Judge and the Realistic Elements of Civil Conflict, First Edition, Libya, Talha Bin Obaid Allah Center for Printing, Publishing and Distribution, Thursday 2006.

30- Muhammad Ahmed Abu Zaid: Rules for Causing Criminal Judgments and Rules for Drafting Criminal Judgment Statements, applied by the Judges Club, 2000.

31- Mohamed Gamal El-Din Hegazy: The Court of Cassation's oversight on the subject of the criminal case, AlFath for Printing and Publishing, Cairo 2001.

32- Muhammad Jamal al-Din Muhammad Hijazi: Oversight of the Court of Cassation on the subject of the criminal case.

33- Muhammad Zaki Abu Amer: The Imperfection of Error in Criminal Judgment, University Press, 1985.

34- Dr. Muhammad Ali Al-Kik: The Principles of Causing Criminal Judgments in the Light of Jurisprudence and the Judiciary, the publisher of the Radiation Library, Alexandria, 1988.

35- Muhammad Ali Swailem: Adaptation in Criminal Matters, University Press, 2005.

36- Muhammad Fahim Darwish: The Art of Judiciary between Theory and Practice, Civil and Criminal Trials, First Edition, Al Zahraa Press for Arab Media, 2007.

37- Mahmoud Yaqubi: Lessons of Formative Logic, Diwan of University Publications, 1993.

38- Hilali Abdul-Ilah Ahmed: The Truth between General and Islamic Philosophy and the Philosophy of Criminal Evidence, second edition, Arab Renaissance House.

39- Youssef Al-Masarwe: Causing Judgments According to the Civil Procedure Code, publisher, International Scientific House and Culture House for Publishing and Distribution, first edition, 2002.

40- Youssef Muhammad Al-Masarwe: Causing judgments according to the Civil Procedure Code, publisher, International Scientific House, and Culture House for Publishing and Distribution, first edition, 2002.

Cassation decisions:

Criminal Cassation No. (39/99) Attorney Association Journal, Issues 9 and 10 of 1999.

Criminal Cassation No. (521/99) Judicial Journal, Third Year, Issue Seven, 1999.

Criminal Cassation No. (672/97) Attorney Association Journal issues 2 and 4 of 1998.

Criminal Cassation No. (732/2003) dated 7/29/2003, Adalah Publications.

Criminal Cassation No. (754/97) Attorney Association Journal issues 3 and 4 of 1998.

Criminal Cassation No. (767/97) Attorney Association Journal issues 2 and 4 of 1998. 